\title{
HUMAN SPECIMEN PLASTINATION BY USING SYNTHETIC PLASTC POLYMER
}

\author{
Chaudhary J. ${ }^{1}$, Supriya K. ${ }^{2}$, Singh S. ${ }^{3}$, Shah S.K. ${ }^{4}$
}

\begin{abstract}
Plastination is a preservation technique which keeps human specimen in natural, dry, hard and odour less state. This is introduced by Dr. Gunther Van Hagen. Recently, anatomists are doing research in plastination to give durable and better human specimen for demonstration tool, museum specimen without formalin irritation. In the department of anatomy, plastic polymer and chloroform is used in plastination. The formalin fixed specimens are dehydrated in acetone. Then transferred to polythene polymer mixer for impregnation and harden in natural drying process. At the end dry, hard and odour less specimens are obtained. In our experience plastination shows the plastinates are natural, dry, hard and odour less state can be an excellent medical educational tool.
\end{abstract}

KEY WORDS: Human specimen, Plastination, Plastic polymer

1, 2,3 \& 4. Lecturer, Department of Anatomy, Universal College of Medical Sciences \& Teaching Hospital, Bhairahawa, Nepal

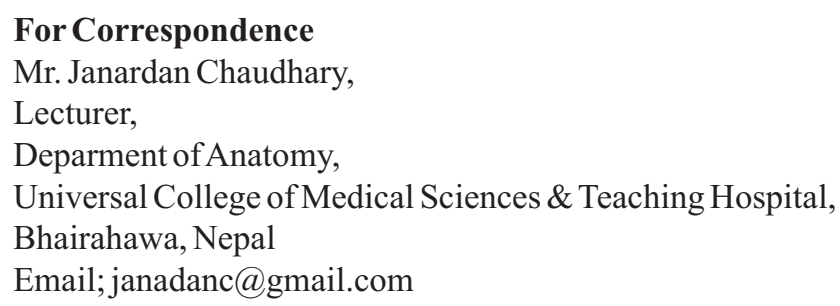


Plastination is a technique of preservation of anatomical specimen by impregnation with curable silicon, epoxy or polyster resin, which keeps the anatomical specimen in dry, natural and odourless state. This study aim to facilate the procedure in simple way and reduce cost of plastination by using plastic polymer. The plastination technique introduced by Dr. Gunther Von Hagens in 1978 is a cornerstone procedure for avoiding hazardous agent used in conventional specimen preparation. In the process of silicon impregnation, a specimen is kept under vacuum in cold temperature for a long period. Anatomist uses silicons (s3 \& s10) during impregnation usually. $\mathrm{Zu}-\mathrm{Yi}$ Chinese silicon polymer was used for impregnation at room temperature (Zhen Tianzhong et al. 1998). Shin- Etsu silicon 108 and imidazole is transparent, colourless polymer used in impregnation (Y.Sakamoto et al. 2006). Biodour ${ }^{\mathrm{TM}} \mathrm{S} 10$ silicon technique was applied to reduce specimen shrinkage (K. Dejong et al. 2007). Biodour S3 and S6 (gas cure)is used to harden in slow and fast methodology (Andreas et al. 1993). In the study, Synthetic plastic polymer i.e. polythene polymer (plastic teacups, water bottle, acrylic sheet) is manufactured by polymerizing styrene using peroxide catalyst. The synthetic plastics are hard, transparent and non biodegradable. Chloroform is highly evaporating and hardening agent. It can breaks down the linkage of plastic polymer. Chloroform can be mixed with the synthetic plastic polymer to make solution. It can be used as silicon polymer mixture during impregnation is a new technique applied in the plastination. As the plastinates are products of the plastination which can be handled easily, durable and devoid of noxious effects of formalin. They are portable and excellent tools in demonstration, dissection and lecture class. They can be used to display as a museum specimen. Plastinate are easy to handle and require minimal aftercare. They can be stored in cupboard, which reduces the cost as well as the irritation and potentially harmful chemical such as formalin.

\section{Specimen collection}

Specimens were selected and dissected. Capsule of soft organs (kidney and spleen) was removed. Muscles and fascia were removed from the pelvis bone. Fascia around vessel was removed at hilum.

\section{Fixation}

Selected and dissected specimens were fixed by immersing in $10 \%-20 \%$ formalin at room temperature for 3-5 days. The fixative reagent was kept 5 times the volume of specimen in the glass jar. After fixation, the specimens were washed under running tap water for a day.

\section{Dehydration}

The specimens were dehydrated in series of 70\%, 80\%, 90\% and absolute acetone for one day each. Absolute acetone continued 3 days more for completion of dehydration and degreasing.

\section{Plastic polymer mixer preparation}

Labels and leads were removed from the bottle. The along with other tea cups, acrylic sheet were washed under tap water and dried. They were made into pieces. $10 \mathrm{gm}$ pieces of plastics polymer for 1litre chloroform were mixed to make the solution. Polythene polymer mixer was prepared by 1:10 ratio of polythene polymer (plastic tea cups, bottle and pieces of acrylic sheet) and chloroform.

\section{Impregnation}

The specimen was transferred to solution air tight jar for impregnation for a week. Impregnation was completed by noting cessation or reduction of bubble formation from specimen.

\section{Natural drying process}

Excess impregnated solution was whipped on surface of specimens and specimens were wrapped with foil for a day. It again unwrapped to harden the specimen natural air drying way. Specimens were polished with varnix (clear) to make it shinny. Now, specimens are ready to use and keep in museum.

The external features of the plastinates are natural like preplastinated specimen. Dry, hard and odour less specimens are obtained.
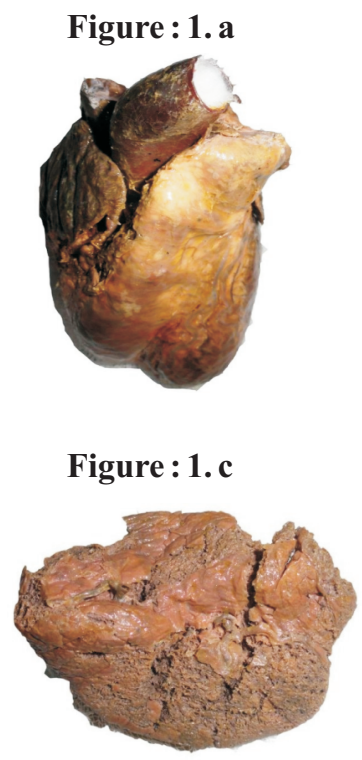

Figure : 1.c
Figure : 1.b

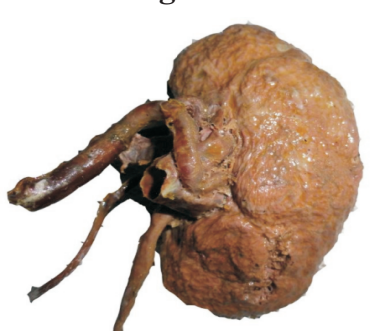

Figure : 1.d

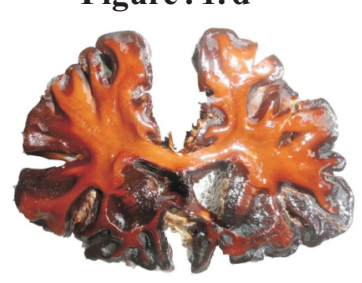

Figure: 1. e

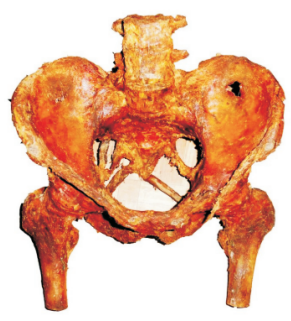


Figure 1: Plastinates of :
a. Heart
b. Kidney
c. Spleen
d. Coronal section of cerebrum
e. Pelvis

\section{DISCUSSION}

Preservation of anatomical specimen retain much of natural features, long lasting is ultimate goal of anatomist, pathologist and other medical educators. This study tried some extent of this goal in the Department of Anatomy, UCMS.

Specimen were first selected, dissected, and then fixed under $10 \%$ formalin. Then these were dehydrated in acetone in ascending manner in a closed jar so that the acetone did not evaporate. The specimens were transferred to polythene polymer mixer. The mixer was mixed with the chloroform which helps to harden the tissue during the impregnation.

Non biodegradable synthetic plastics are hazardous to environment which can cause harmful effect to human health. This is remarkedly task done via plastination in the field of medical sciences can use synthetic plastic polymer. Plastic are durable and free of micro-organisms for specimen tissue. Solution prepared in the study can penetrate deep to the tissue. Chloroform is hardening agent can evaporate easily. The plastinates are outcome of this study. These are natural, portable, nontoxic and durable. Easy handle and examination of plastinates without any nontoxic effect makes plastinate an excellent teaching tool for anatomy, pathology and other medical educators.
Plastination is available method which is very simple to do. The plastinates are natural, dry, hard and odourless. The 10\%$20 \%$ shrinkage is observed in specimen after the plastination.

\section{REFERENCES}

1. Andreas H, Weiglein, Henry RW, Curing (Hardening, Polymerization) of The Polymer-Biodur S10, J. Int Soc Plastiantion, Vol 7, 1993, 32-35.

2. Raoof A, Henry RW, and Reed RB, Silicon Plastination Of Biological Tissue; Room Temperature Technique Dow/Corcoran Technique And Products; J. Int Soc Plastiantion, Vol 22, 2007, 25-30

3. Darawiroj D, Adirekthaworn A, Sriswathansakul S, et al, Comparative Study of Temperature Used In Silicon Impregnation Of Porcine Heart Plastination, Proc. $9^{\text {th }} \mathrm{CU}$. Vet. Scie. Ann 2010.

4. Suganthy J, Francis DV, Plastination Using Standard $\$ 10$ Technique, J. Anat. Soc. India 61(1) (2012) 44-47.

5. Dejong $K$ and Silicon RW, Plastination of Biological Tissue, Cold Temperature Technique Biodur S10/S15 Technique and Products, J. Int Soc Plastiantion, Vol 22, 2007, 2-14.

6. Timothy $R$, Bames AA, LFDet al., Plastination Of Neroanatomical Anad Anatomical Specimen, KOPF Instrument Tujunga, California, No 26 July 1990.

7. Tianzhong Z, Jingren T, and Kerming Z, Plastination At Room Temperature, J. Int Soc Plastiantion, vol 13, No2; 1998, $21-25$.

8. Sakamoto Y, Miyake Y, Kanahara, Kajita H, et al, Chemically Reactivated Plastiantion With Shin-Etso Silicon KE-108, J. Int Soc Plastiantionvol21, 2006, 11-16.

\section{SUBSCRIPTION CHARGES}

\begin{tabular}{|c|c|c|}
\multicolumn{1}{c}{} & $\begin{array}{r}\text { INSTITUTION } \\
\text { Single copy/Annual }\end{array}$ & \multicolumn{1}{c|}{$\begin{array}{l}\text { INDIVIDUAL } \\
\text { Single copy/Annual }\end{array}$} \\
\hline NEPAL & NRS. $300 / 1000$ & NRS. 200/700 \\
\hline SAARC COUNTRIES & IRS. 300/1000 & IRS.200/700 \\
\hline OTHER COUNTRIES & US\$ 40/100 & US $\$ 20 / 75$ \\
\hline
\end{tabular}

\section{ADVERTISEMENT CHARGES}

\begin{tabular}{|c|c|c|}
\hline S.NO & PAGE & RATE (NC) \\
\hline 1. & FULL BACK COVER & 15000 \\
\hline 2. & FULL INSIDE OF FRONT \& BACK COVER & 12000 \\
\hline 3. & FULL INSIDE & 10000 \\
\hline 4. & HALF SIDE & 8000 \\
\hline 5. & QUARTER & 4000 \\
\hline
\end{tabular}

